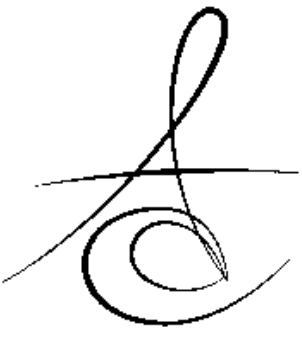

\section{REHABILITATION OF MAXILLECTOMY CASE WITTH CONVENTIONAL RETAINED OBTURATOR PROSTHESIS: A CASE REPORT}

\section{MAKSİLLER REZEKSİYONUN GELENEKSEL TUTUCULU OBTURATÖR İLE REHABİLITTASYONU: VAKA RAPORU}

\author{
Arş. Gör. Muhammet KARCI* Dr. Öğr. Üyesi Necla DEMİR*
}

Makale Kodu/Article code: 3044

Makale Gönderilme tarihi: 01.10 .2016

Kabul Tarihi: 02.02.2017

\section{ABSTRACT}

Maxillary resection performed for removal of the tumor mass, leads to esthetic, phonetic, functional and important psychological problems for the patient. The primary aim of prosthetic rehabilitation is to close the maxillary defect and eliminate such problems by use of different bulb designs. An obturator is a treatment option for the defects after maxillary tumor surgery. In this article, rehabilitation with hollow bulb obturator prosthesis was explained for a patient subjected to maxillary resection because of tumor mass.

Keywords: Maxillary defect, obturator, hollow bulb, prosthetic rehabilitation

\section{öz}

Tümör kitlesini ortadan kaldırmak için yapılan maksiler rezeksiyon hastalar için estetik, fonetik, işlevsel ve önemli psikolojik sorunlara yol açar. Protetik rehabilitasyonun öncelikli amacı farklı bulb dizaynlarını kullanarak maksiller defekti ve buna bağlı bazı problemleri ortadan kaldırmaktır. Obturatörler, maksiller tümör cerrahisi sonrası oluşan defektler için bir tedavi yöntemidir. Bu makalede, tümör kitlesi nedeniyle maksiller rezeksiyon yapılan bir hastanın hollow bulb obturatör protez ile rehabilitasyon anlatılmaktadır.

Anahtar Kelimeler: Maksiller defekt, obturatör, hollow bulb, protetik rehabilitasyon

\section{INTRODUCTION}

Defects of the maxilla may result by trauma, disease, pathological changes or following surgical resection of oral neoplasm. Maxillectomy defects result in the formation of an opening between the oral cavity and the antrum or the nasopharynx. ${ }^{1}$ Despite advances in surgical procedures, surgical reconstruction of maxillectomy defects is not always possible because of the general health condition of the patient. ${ }^{2}$ Prosthetic obturator was the primary method employed in rehabilitating larger maxillary defects. ${ }^{3}$ The reconstruction or obturation of the surgical defect prevents air, liquid, and food from escaping into the antrum or the nasopharynx, thus provading normal speech and swallowing function and ultimately quality of life. ${ }^{4} \mathrm{~A}$ successful prosthetic design for functional restoration after maxillectomy uses the remaining palate and dentition to maximize the support, stability and retention of an obturator bulb.

An unfavorable situation for prosthetic rehabilitation happens when the size of a defect is so large that it overwhelms the remaining structures that stabilize a prosthesis over the defect. Instability of the obturator results in air and fluid leakage through the nasal cavity and thereby compromises function. ${ }^{5}$ So the primary goal of prosthetic obturation is closure of the maxillectomy defect and separation of the oral cavity from the nasal cavity in order to prevent hypernasal speech and liquid leakage into the nasal cavity. ${ }^{6}$ This case report demonstrates prosthetic rehabilitation of a patient subjected to maxillary resection because of tumory mass with conventional retained obturator prosthesis.

*Selcuk University, Faculty of Dentisty, Department of Prosthodontics, Konya 


\section{CASE REPORT}

A 65-year-old man was referred after his maxillectomy surgeon to the Department of Prosthodontics at the Selcuk University, Faculty of Dentistry in Konya, Turkey for an evaluation for prosthetic treatment. His medical history revealed that the patient had been operated for "Squamous cell carcinoma" of maxilla one year ago and rehabilitated with radiotherapy. After 6 months the patient revisited the dental center seeking definitive rehabilitation. Intra-oral examination revealed an existing surgical defect with adequate healing and there were no natural teeth remaining in the mandibular and maxillar arch (Figure 1). Treatment plan was formulated with obturator prosthesis for the maxillar arch and mandibular complete denture. The patient's major complaints were lack of retention, instability of the prosthesis, impaired speech, mastication and liquid leakage into the oral cavity. Extra-oral examination revealed like edentulous patients. Intraoral examination showed resectioning of the hard palate, alveolar bone, teeth and soft tissue in posterior maxilla until soft palate. The patient did not accept implant surgery that's why we preferred the conventional obturator prosthesis retained by the defect area. A primary impression was made using irreversible impression material (Soft Hydrogum, Zhermack, Rovigo, Italy) and poured in Type IV dental stone (Dentstone; Pankaj Industries, Mumbai, India). The diagnostic cast was surveyed for fabricating autopolymerizing acrylic resin special tray. The final impression was made by zinc oxide eugenol (SS White Group, England) for mandibular arch and irreversible impression material (Soft Hydrogum, Zhermack, Rovigo, Italy) for maxillary arch with special tray. Occlusal relationship were secured and mounted in a semiadjustable articulator. Teeth position and occlusion were checked, and the necessary corrections were made before processing the dentures (Figure 2). A hollow-bulb obturator prosthesis was processed from heat-polymerizing acrylic resin using conventional laboratory procedures (Lucitone 199; Dentsply, Austenal, New York) (Figure 3) and delivered to the patient (Figure 4). Treatment was completed to the aesthetic and functional satisfaction of the patient, who has been using his prosthesis for 3 months with no complaints. The patient was provided with oral hygiene instruction, and called for follow-up evaluations after 6 months.

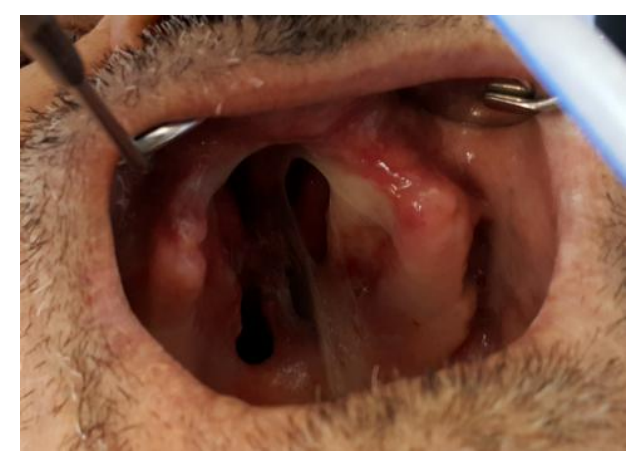

Figure 1. Intraoral view of patient.

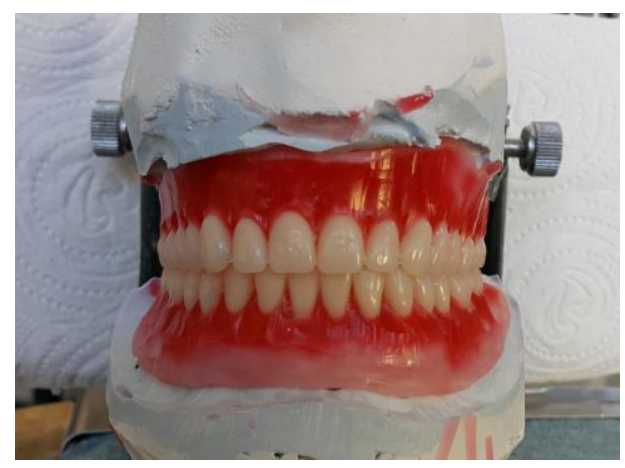

Figure 2. Teeth position and occlusion.

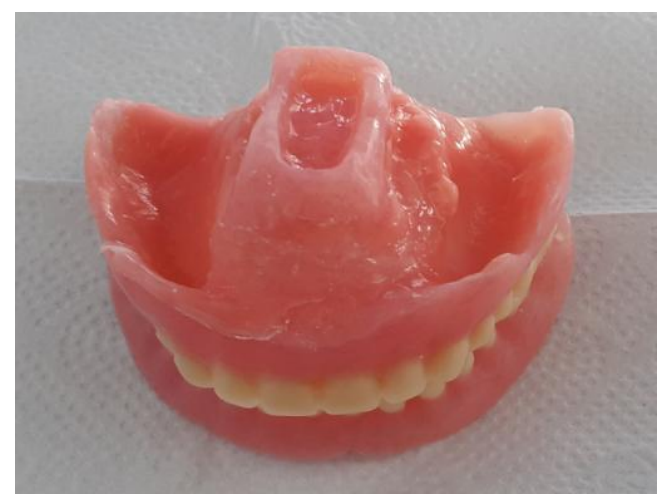

Figure 3. Processed prosthesis. 


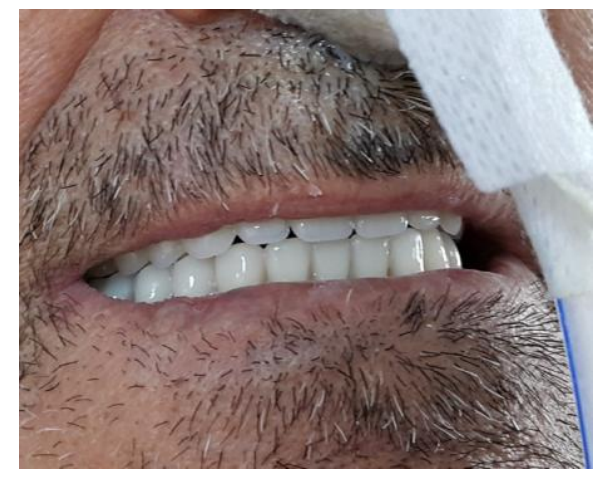

Figure 4. Final appearance.

\section{DISCUSSION}

The obturator prostheses were generally used in rehabilitating maxillary defect. A well-designed obturator prostheses for maxillary defects were not only to maintain durable and good retention, stability and support, but also to relieve pain, esthetic and psychological problems and result in ease of use. One of the most crucial parts for application of obturator prosthesis is the retention of prosthesis. ${ }^{7}$ Based on location and size of defect, health conditions of remaining teeth and bones, available soft tissue undercuts and muscular control, various obturator prostheses with different retentive designs were used to improve oral functions: Conventional designed, attachment enhanced or magnet enhanced. ${ }^{8}$ Conventional retained obturators, retention can be provided by hollow bulb or buccal extension. ${ }^{9}$ The bulb, or part of prosthesis extending into the defect, is generally hollow to reduce the weight of the obturator. Different techniques have been described to fabricate hollow bulb obturators but the simplest method is to grind out the interior of the obturator bulb after acrylisation. ${ }^{10}$ Bulbs are divided into three groups according to materials they are made: hard, soft, hard and soft. ${ }^{11}$ Stud attachments were economical, easy-replaced, and one of the most important benefit was reduction of the unbalanced stress on the abutment teeth. But the tooth adjacent to the defect suffered many overburden outside forces, resulting in rapid periodontal damages of the tooth. Prosthesis retained by magnetic attachment was widely used in strengthening retention. ${ }^{9}$ With the development of research and improved techniques, there were various strategies, designs and materials to achieve enhanced retention, such as perfect attachment supported by implant retentive obturator prosthesis. ${ }^{12}$ Osseointegrated implants have been successful in providing retention, stability, and support of dental and craniofacial prostheses.

Unfortunately, in various situations, the loss of adequate osseous structures and economical and healthy problems makes implant placement difficult and less predictable. ${ }^{13}$ In these situations, conventional designed obturator prosthesis can compensate patient's problems.

\section{CONCLUSION}

Obturator prostheses mainly depend on outcomes of maxillofacial reconstruction and rehabilitation involving functions, esthetics, phonetic, psychology acceptance and resocialization. It can be provided by conventional retained obturator prosthesis.

Muhammet KARCI: ORCID ID: 0000-0002-7101-822X Necla DEMİR: ORCID ID: 0000-0003-0927-6962

\section{REFERENCES}

1. Taylor TD. Clinical maxillofacial prosthetics. Quintessence Publishing Co: 2000. p. 103-20.

2. Roumanas ED, Nishimura RD, Davis BK. Clinical evaluation of implants retaining edentulous maxillary obturator prostheses. J Prosthet Dent 1997;77:184-90.

3. Dingman C, Hegedus PD, Likes C, McDowell P, McCarthy E, Zwilling C. A coordinated, multidisciplinary approach to caring for the patient with head and neck cancer. J Support Oncol 2008;6:125-31.

4. Jacob FJ. Clinical management of the edentulous maxillectomy patient. Quintessence Publishing Co: 2000. p. 85-7.

5. Minsley GE, Warren DW, Hinton V. Physiologic responses to maxillary resection and subsequent obturation. J Prosthet Dent 1987;57:338-44.

6. Okay DJ, Genden E, Buchbinder D, Urken M. Prosthodontic guidelines for surgical reconstruction of the maxilla: A classification system of defects. J Prosthet Dent 2001;86:352-63.

7. Aramany MA. Basic principles of obturator design for partially edentulous patients. Part II: Design principles. J Prosthet Dent 2001;86:562. 
8. Grossmann Y, Madjar D. Resin bonded attachments for maxillary obturator retention: A clinical report. J Prosthet Dent 2004;92:229-32.

9. Cheng C, Wenhao R, Ling G, Zheng C, Linmei Z, Shaoming L, Pro Ke-qian Z. Function of obturator prosthesis after maxillectomy and prosthetic obturator rehabilitation. Braz J Otorhinolaryngol 2016;82:177-83.

10. Didier M, Laccoureye O, Brasnu D, Vignon M. New surgical obturator prosthesis for hemimaxillectomy patients. J Prosthet Dent 1993;69:520-3.

11. Yazıcıoğlu H, Yaluğ $\mathrm{S}$, Akalın MR. İki farklı obturatör yapım yöntemine göre dişler arasındaki boyutsal farklıı̆ı̆n değerlendirilmesi. Atatürk Üni Diş Hek Fak Derg 2001;11:28-32.

12. Candel-Marti E, Carrillo-Garcia C, Penarrocha-Oltra D, Penarrocha-Diago M. Rehabilitation of atrophic posteriormaxilla with zygomatic implants: review. J Oral Implantol 2012;38:653-7.

13. Roumanas ED, Nishimura RD, Davis BK, Beumer J 3rd. Clinical evaluation of implants retaining edentulous maxillary obturator prosthesis. J Prosthet Dent 1997;77:184-9.

\section{Yazışma Adresi}

Muhammet Karcl

Selcuk University, Faculty of Dentistry, Department of Prosthodontics

Campus / KONYA

Phone: +90-332-2410041/1186

Fax: $+90-332-2410062$

e-mail:muhammetdt48@hotmail.com 